\title{
"FAKE PRODUCT? WHY NOT!" ATTITUDES TOWARD THE CONSUMPTION OF COUNTERFEIT GOODS IN CEE AS SHOWN ON THE EXAMPLE OF SLOVAKIA
}

\author{
Kasl Kollmannová, D.
}

This article focuses on the increasing consumption trend of counterfeit goods in the countries of CEE and on the consequences for the global market. Counterfeiting is no longer typical only for the luxury market, where branding together with genuine source play a crucial role and the business of top luxury has been rising during the crisis. New categories of counterfeit goods are emerging constantly, including electronics and computer parts, pharmaceuticals, and even FMCG such as food, beverages or cosmetics. This article presents data from GfK research on attitudes towards counterfeit goods in Slovakia and puts it into the context of other CEE countries. It gives clear managerial implications on how to communicate the importance of originality, benefits for the consumer when consuming original goods and social marketing of ethical consumption. The managerial implications are specifically targeted for luxury businesses, on-line shops and FMCG producers.

JEL Classification: M30

\section{Introduction}

In the times of economic crises, people's attitudes towards investing and spending money are changing. While the financially worse off consumers tend to buy cheaper products, such as private labels, non-branded or even fake goods, rich consumers are investing more into products on the opposite end of the price scale and the luxury market is growing. The market with counterfeit goods is growing, and it is no longer just a matter of copying luxury fashion goods. Counterfeiting represents about $5-8 \%$ of world trade and is nowadays less risky and more profitable than drug trafficking (Penz, Schlegemilch and Stöttinger, 2009, p. 67).

The global market for counterfeit goods is showing some interesting trends, which have direct effects on the European market. However, we cannot take the European market as one - the attitudes towards buying fake goods are different mainly in the Western and Eastern parts of Europe, which each have a different history, social values and also education towards counterfeit goods. Consuming counterfeit goods does not only have implications on the economy, such as a rise of the black market and tax avoidance, but also lowers the general morality in a society. In extreme cases, consuming fake products - which of course do not always respect the technical and health norms of production - can lead even to health risks, such as in the case of counterfeit alcohol consumed in the Czech Republic, where 28 people died after consuming alcohol contaminated with methanol
(October 2012 ${ }^{1}$ ). This article will examine the rising trend of consumption of counterfeit goods in Europe and, based on the example of Slovakia, will explore the consumer behavior and attitudes towards consumption of counterfeits. In the end, it will give clear managerial implications on marketing communication and support of ethical consumption in CEE. According to the Report on EU customs enforcement of intellectual property rights $(2012$, p. 3$)$, the total value of detained goods infringing on intellectual property rights $(\mathrm{IPR})^{2}$ in 2011 was over 1.2 billion Euros of domestic retail value. Contrary to popular belief, counterfeit goods are not primarily luxury fashion brands. The top categories of detained articles were medicines, which accounted for $24 \%$ of the overall amount; this was followed by packaging materials $(21 \%)$, cigarettes (18\%), clothing (4\%), accessories for mobile phones and labels, tags and stickers (EU 2012, p. 3). Among the counterfeit products, there are also alcoholic beverages, perfumes, shampoos, watches and jewelry, computer equipment, office stationery and many others. According to Fortmann (2011, p. 21), with the recent

1 Štěrba, R. (2012) Metylalkohol má další obět. iDnes. Retrieved from http://zpravy.idnes.cz/metyalkohol-zabil-muzeZ-uherskohradistska-policiste-nasli-obri-sklad-13a-/krimi. aspx?c=A121008_133308_zlin-zpravy_ras , 2012-10-10

2 Within this article, I use the term "counterfeit goods" instead of the official report term "goods suspected of infringing an IPR" (EU 2012, p. 3). 


\section{Graph 1 Top categories by articles}

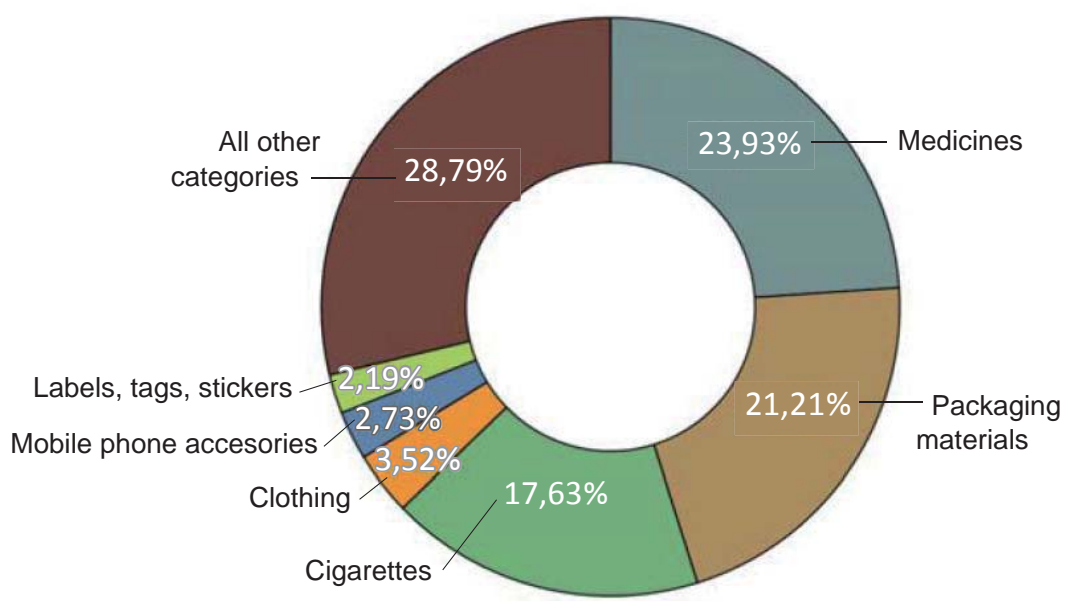

Source: EU, 2012

economic crisis, counterfeiting in Europe is on the rise. After many years of counterfeiting luxury goods in Europe, the producers are now concentrating on counterfeiting more ordinary merchandise.

Clothing itself represents rather a minor category of detained articles, but their domestic retail value (DRV) is high and they are also often detained. For example, a Louis Vuitton handbag can cost up to 2000 EUR, whereas a fake product, made of cheap materials, can be sold on the black market for 7 EUR. However, even more sophisticated cases can be found within the luxury segment sector; take, for example, the case of the luxury fashion brand Hermès, which in cooperation with the police, discovered a complicated network which included some of their own employees who participated in selling the unofficial (thus considered as counterfeit) or copied products under the brand of Hermès on the black market. The copies were made of luxury materials, such as crocodile leather, and with a high level of sophistication (a Hermès original handbag can cost up to 50000 EUR depending on the materials and style). ${ }^{3}$ The difference between fake and original prices is increasing with the intellectual and creative value and/or materials used in the product. Brand value also plays a big role, especially in copying traditional brands such as Hermès (founded 1837), because the counterfeiters are misusing the trust and credibility of consumers, created along with tradition.

"Counterfeiters do not concern themselves with product development costs, guarantees or advertising. Profit is maximized by the theft and copying of an original idea, often

3 Diderich, Joelle. Hermès Hails Breakup of Fake Bag Ring. WWD. On-line. Retrieved from http://www.wwd.com/ business-news/legal/herms-hails-breakup-of-fake-bagring-5966863 2012-06-17 with cheaper materials. Nevertheless, IPR infringing goods are increasingly sold at a price similar to that of the original goods and effectively substitute them on the market" (EU 2012, p. 13-14).

The cases of detained goods rank clothing in second place with almost 20\%, following non-sport shoes at 28\% (EU 2012, p. 13). The EU reported that there is a high increase of goods which are potentially dangerous to the health and safety of consumers, i.e. medicines, food, cosmetics and body care, electrical goods and toys. Whereas in 2010, $14.5 \%$ of these potentially dangerous goods were detained, in 2011 the percentage almost doubled to $28.6 \%$ due to an increase in medicines (EU 2012, p. 13).

\section{Why do people buy fake products?}

When considering a market with counterfeit goods, it is necessary to distinguish between consumers who are buying the fake goods on purpose (deceptive counterfeiting) and those who are misled (non-deceptive counterfeiting) (Grossmann and Shapiro, 1988, Nia and Zaichowski, 2000). Penz, Schlegemilch and Stöttinger (2009) have been widely analyzing the factors which influence consumer behavior and motives for buying fake goods on the example of four countries: Czech Republic, Slovenia, Austria and Mexico. According to the authors, the country-specific findings are erratic rather than following a certain pattern. However, they recommend educating customers about the specific characteristics and values of originals, rather than supporting general education against counterfeits. "The more consumers know about the detrimental impact of counterfeiting, the harder they find it to rationalize their behavior. Thus, informing consumers specifically on the 'business practices of counterfeiters' may help to change their attitudes. In general, specific knowledge still has a stronger 


\section{Graph 2 Categories of fake goods}

Source: GfK, 2010a

impact than general education" (Penz, Schlegemilch and Stöttinger, 2009, p. 80).

Clothes, sportswear, shoes, handbags and watches are still predominant products, when it comes to the question of fake goods in public discourse. According to a survey from Slovakia (GfK, 2010b), 81.4\% of Slovaks have someone among their friends or people they know who own a fake product. T-shirts and sweaters are the most frequent fake goods, followed by sportswear and sport shoes. Sportswear is not worn in the countries of CEE just for sport, fitness or training, but also for other

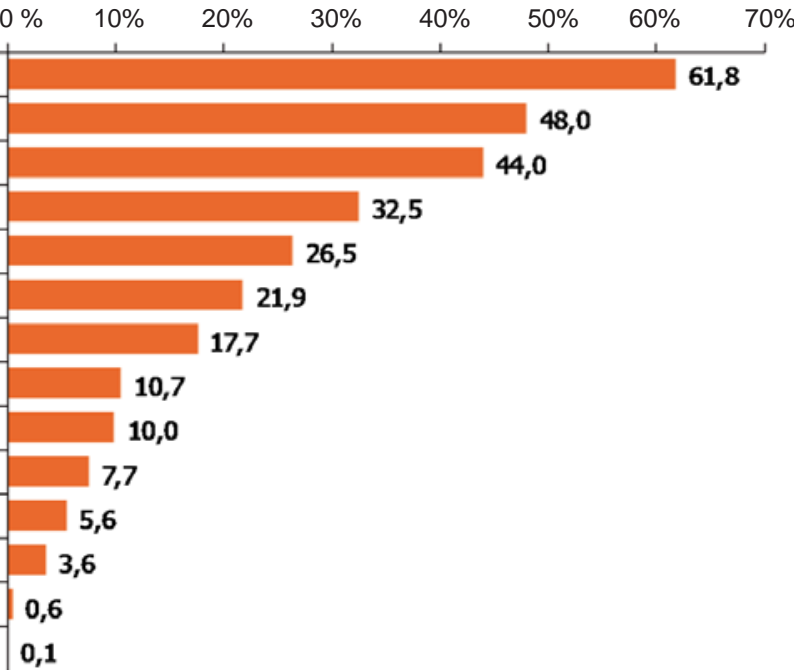

leisure, relaxation or even work occasions. Sport brands, such as Adidas, Nike and Puma thus top the most wanted and most popular counterfeit brands, followed by luxury brands such as Louis Vuitton, Dolce and Gabbana and Gucci. Within the list, also premium fashion brands like Lacoste, Ed Hardy, Guess or Tommy Hilfiger are present. A majority of Slovaks clearly admit that buying or wearing fake products is not associated with public shame or ethical barriers. Only $5.8 \%$ strictly deny they would buy a fake product in the future, whereas almost two-thirds of respondents $(66 \%)$ express their intent to buy a fake product in

Graph 3 Most copied brands according to consumers

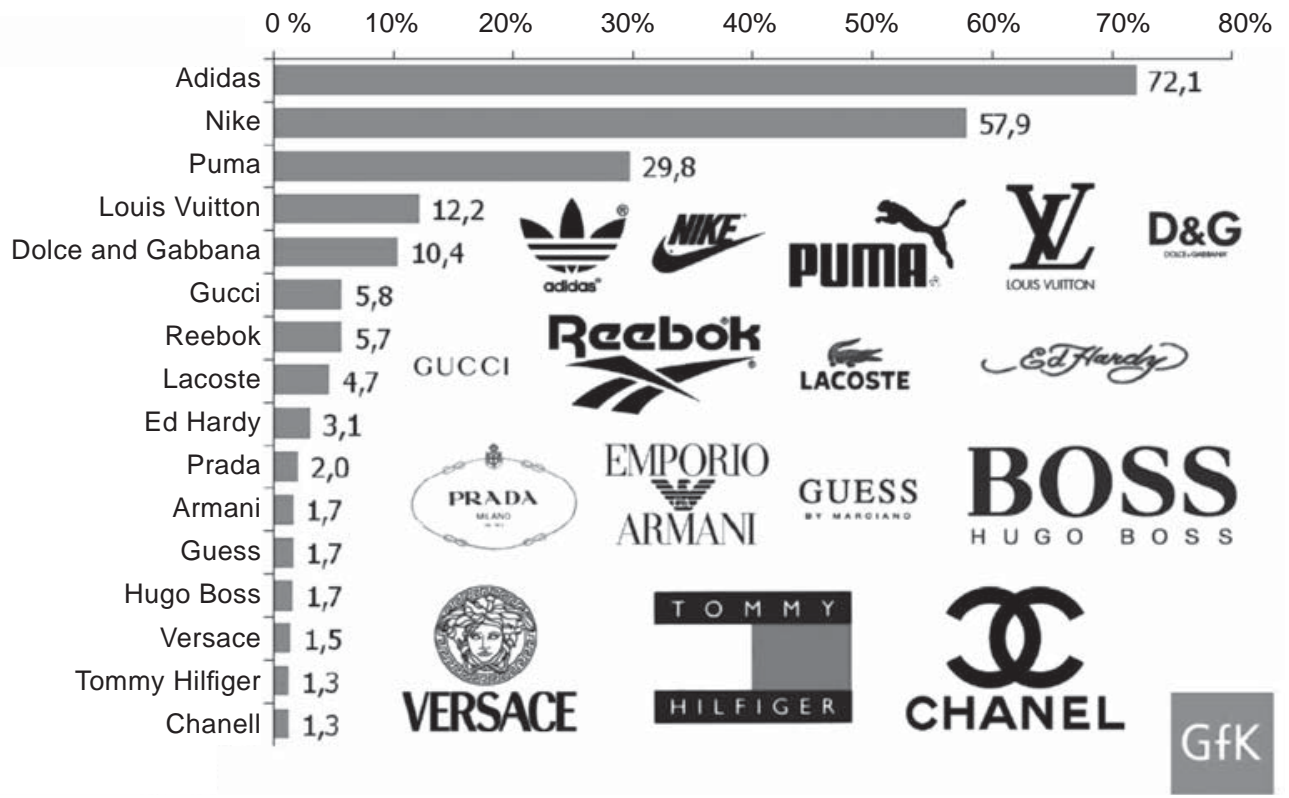


the future. Slovaks would even recommend buying a fake product to a friend if it is around $60 \%$ cheaper than the original; they would be even more likely to do so if it is an item they'll use just a few times (GfK, 2010b). This correlates with the findings of other research, which showed that consumers' purchase decisions follow a much simpler logic than anticipated in the literature - price, even if it is just a 20\% discount (Penz, Schlegemilch and Stöttinger, 2009, p. 81).

Clearly, Slovaks are not afraid to show their non-deceptive counterfeit attitude - they are fully aware they are buying fake items and they do it on purpose; their rationalization of such behavior is simply based on the benefit of price. The question is though whether the non-deceptive attitude is present also for the other categories of products such as pharmaceuticals, healthcare, cosmetics and food. "Here emotions of fear and uncertainty may accompany the purchasing decision, as the fake may not live up to the expected quality, thus nullifying the price advantage" (Penz, Schlegemilch and Stöttinger, 2009, p. 82).

\section{Graph 4 Attitudes towards wearing a fake product if people can't recognize it's fake}

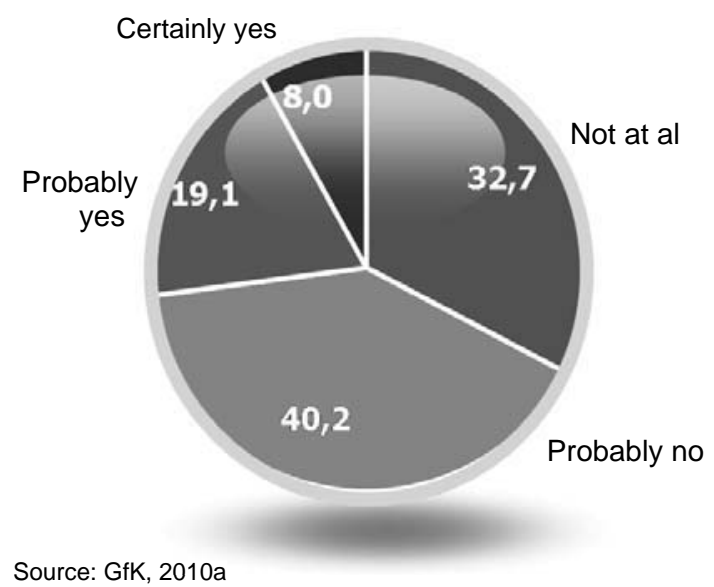

The expressed willingness of Slovak consumers to use fake goods is a trend that will grow in the future without active support for original goods by their producers. When asked what the respondents themselves think about the counterfeit market, i.e. whether the trend of buying fake goods will rise or fall, they mostly support a future rise $(60 \%$, GfK 2010b). On the contrary, China, which is the world's biggest producer of fake goods, is going in the opposite direction. China produces $70.93 \%$ of all counterfeit goods detained in Europe by value, but the counterfeit goods also come, on a minor scale, from European countries such as Germany (2.45\%) and Greece (2.12\%).
Graph 5 Countries of provenance of counterfeit goods by value

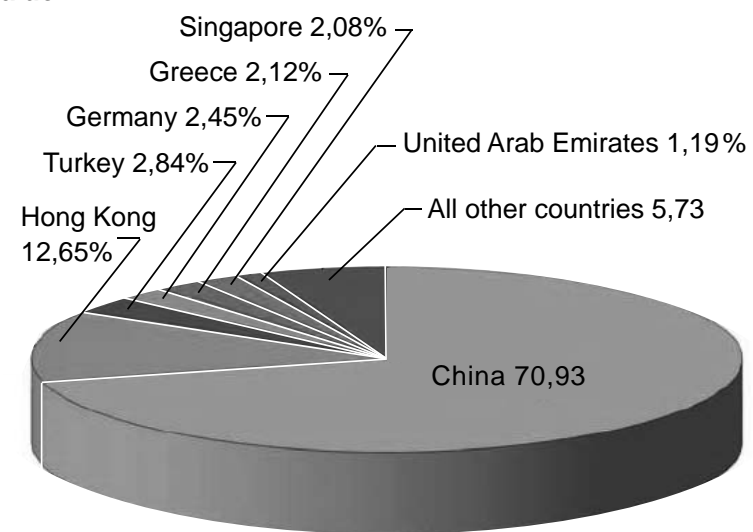

Source: EU, 2012

According to a McKinsey study (Burkitt, 2012), Chinese consumers expressed less willingness to buy fake goods in 2010 (15\%) than in 2008 (31\%). In China, the cultural factor of not "losing face" creates strong social pressure when it comes to consumption, yet just the opposite when it comes to production. According to a Bernstein Research (2010) market analysis, "China is likely to remain a key engine of luxury demand growth in the long term, as its economic development continues. In the current Chinese expansion we see several parallels with that of Japan 40 to 50 years ago - yet bigger and more aggressive.” Yet we can presuppose that the intercultural difference (Hofstede, 2001) which might be similar in China, Japan and India, will not be transferable to CEE countries. On the other hand, most likely, the attitudes toward fake goods will show a similar trend in Slovakia, Czech Republic, Poland or Hungary - it is necessary to further research this. The prediction might sound provocative, but according to presented data, it is more than realistic; Europe will consume counterfeit goods and lose its intellectual property profits, whereas China will profit from producing such fake goods for markets like Europe and then consume the originals.

\section{Results}

To sum up the presented data, we can assume that selling counterfeit goods of all sorts in CEE is a widespread and growing problem. The market with counterfeit goods in Central Europe is growing and it's harder to avoid the risks connected with counterfeits.

According to EU data, most of the goods are imported and come from China; $92 \%$ of the goods are imported professionally in large volumes (commercial trafficking), yet with the increase of on-line shopping, the number of goods detained by passenger traffic (mainly post) is rising. The controls 
on the national levels within the CEE states are getting more effective; however, some countries are making better progress than others. For example, between 2010-2011, the number of procedures rose by $27 \%$ in Czech Republic, $60 \%$ in Romania and by $364 \%$ in Slovakia, but in other countries, the number of procedures fell down: by $13 \%$ in Hungary, $15 \%$ in Poland, $39 \%$ in Bulgaria and even $18 \%$ in Germany (EU, 2012, p.21).

When it comes to counterfeit goods, it's not just fake Louis Vuitton handbags. Products of daily use, such as cosmetics, food or even pharmaceuticals, are being counterfeited more often. Products for daily use and products that would be potentially dangerous to the health and safety of consumers (i.e. suspected trademark infringements concerning food and beverages, body care articles, medicines, electric household goods and toys) accounted

for a total of $28.6 \%$ (compared to $14.5 \%$ in 2010) of the total amount of detained articles due to the increase in medicines (EU, 2012, p.3).

The unusually low price, shopping stall or foreign nationality of a retailer is no longer a warning sign of a counterfeit article, as a recent case in Czech Republic showed. More than 28 people died and many were injured after drinking professionally counterfeited alcohol, which was sold in local shops or popular restaurants (Štěrba, 2012). In the Czech Republic, fake luxury goods, such as handbags and watches were confiscated in the high-end shopping malls of Kotva or Palladium in Prague's city center (Nevyhoštěný, 2012).

As the research done by GfK (2010b) in Slovakia showed us, the consumption of fakes is not considered by the majority of society as something they should be ashamed of. Most people think that almost everyone else is buying counterfeit goods; in addition, they do not even hesitate to admit that they buy them too. However, when it comes to counterfeits, both sides - the producer and the consumer are participating in an illegal act; this is despite the fact that within $\mathrm{CEE}$, the buyers are not being punished as they are in Italy or France, where people can pay up to 10,000 EUR for buying a handbag for 7 EUR or possibly even be jailed as in France (BBC, 2009).

Despite some attempts to prevent consumers from buying counterfeits and to educate them in ethical consumption or health risks connected with the consumption of fake goods - e.g. the European Commission's campaign against counterfeit toys - governments are not putting the protection of IPR in first place when launching social campaigns (EU Business, 2012). More attention is of course given to topics such as speeding or domestic violence which endanger the lives of citizens every day in a more direct manner.

\section{Managerial implications}

Counterfeiting and IPR protection are broad topics, which cannot be put simply together with one recommendation for all companies. Thus I will focus only on the three segments of the market, which were analyzed within this article and for which clear managerial implications and examples can be given.

\section{Luxury companies and high-end products}

Until recently, luxury companies have been holding mainly the position that owning their products is linked with a sense of high social status, i.e. one that does not allow their consumers to even think about buying a fake, because they would be 1) humiliated by their peers and 2) so ashamed of themselves. But with the rise of on-line shopping even by the top class of consumers and with the penetration of fake goods into affluent environments, it is necessary to change the communication strategy and start to communicate the specific qualities and distinguishing marks, which are an integral part of luxury goods. Uniting several brands or companies within the luxury segment can help raise the credibility and importance of the issue; take, for example, the campaign of the 'Fondation de la Haute Horologie', which started a campaign against fake Swiss watches under the slogan "Fake watches for fake people" (Haute Horologie, 2011). Concentrating more on the honesty and personal pride of the consumer in public relations and communication specifically in the European market is essential (on the contrary to Asia, specifically China and Japan, the world's top luxury markets, where the sense of personal pride and threat of social shame is much higher).

\section{On-line shops}

As more and more counterfeit goods are being sold to individual customers all over the world via on-line shops, the retailers must state clearly where the goods come from. This is especially important for fashion and technology retailers, which sell branded goods such as handbags, shoes, computers or watches for discount prices. The retailer is psychologically more distant than a brick-and-mortar store, which creates more demand on the credibility. Also, within the on-line world, one individual's bad experience can cause a massive negative word-of-mouth campaign. For on-line shops, it would be easy to create an application on how to check technological protection and original packaging of the product; however, the original must always be approved only by the producer, not the reseller. The case of Czech on-line fashion server Zoot (via sales-server Slevomat) showed that one customer - after buying a fake Lacoste T-shirt had a lot of hassle proving that the T-shirt was not original, spent months waiting to get the money back and received no apology from the on-line server at all (Kohoutová, 2012). 


\section{Daily use products and pharmaceuticals}

In this category, public sector institutions and private companies should cooperate hand in hand and launch several social marketing and public relations campaigns that would alert the public that the danger of counterfeit goods is not "just" a fake handbag or pirated software anymore, but it can be anything from toys, drinks, chocolates or medicines. Pharmaceutical companies should launch specific social marketing campaigns communicating potential health risks, for example, what happens when consuming fake Viagra. Within the media, the sellers of counterfeit goods are stereotypically portrayed as foreigners wondering around their stalls and selling clothes or handbags. Communicating other facts, such as the example of fake goods in luxury shopping malls (showed above), is a good example for state control institutions such as the Czech Trade Inspection Authority.

To sum up, the overall managerial implication for all producers of branded goods is to not underestimate, avoid or ignore the counterfeit market. Both producers and retailers should cooperate with government institutions to raise the awareness of risks associated with counterfeit goods via social marketing and public relations campaigns. Concretely, they should invest more in their own communications to raise the knowledge of basic distinguishing marks of the original product to avoid deceptive consumption, create more trust towards the retailers, and if any suspicion regarding selling counterfeits within their company occurs, react immediately and transparently. Because trust is like a mirror - you can't fix it if it's broken.

\section{References}

BBC (2009). Tourists warned over fake goods, (accessed August 05, 2012), [available at http://news.bbc.co.uk/2/hi/ uk_news/8215519.stm].

Bernstein Research (2010). European Luxury Goods: The Anatomy of Overseas Luxury Markets. Black Book European Luxury Goods: The Anatomy of Overseas Luxury Markets, 1-224.

Burkit, L. (2012). Chinese Shoppers Lose Taste for Fakes. Wall Street Journal, (accessed June 01, 2012), [available at http:// on-line.wsj.com/article/SB100014240529702046426045772 12810205146048.html].

Diderich, J. (2012). Hermès Hails Breakup of Fake Bag Ring. WWD, (accessed June 17, 2012), [available at http://www.wwd.com/business-news/legal/ herms-hails-breakup-of-fake-bag-ring-5966863].

EU Business (2012). Brussels launches campaign against counterfeit toys, (accessed August 05, 2012), [available at http://www.eubusiness.com/ news-eu/counterfeit-toys.hy8].

European Union (2012). Report on EU customs enforcement of intellectual property rights. Results at the EU border 2011, (accessed August 10, 2012), [available at http:// ec.europa.eu/taxation_customs/resources/documents/ customs/customs controls/counterfeit piracy/ statistics/2012_ipr_statistics_en.pdf].

Fortmann, C. (2011). Counterfeiting Trends and Litigation Shaping the Licensing Industry in Europe. IP Litigator, 17 (2): 20-29.

GfK (2010a). Slovaks' attitude to fake goods. GfK Slovakia. Press Release, (accessed May 01, 2012), [available at http:// www.gfk.sk/public_relations/press/press_articles/006833/ index.en.html].

GfK (2010b). Slovaks' attitude to fake goods. GfK Intraco Special Research. GfK Slovakia. Internal Data.

Grossman, G. M., Shapiro. C. (1988). Foreign counterfeiting of status goods. The Quarterly Journal of Economics, 103 (1): 79-100.

Haute Horologie (2011). Anti-counterfeiting Campaign, (accessed August 05, 2012), [available at http://www.hautehorlogerie.org/en/fondation/ fight-against-counterfeiting/anti-counterfeiting-campaigns].

Hofstede, G. (2001). Culture's Consequences: Comparing Values, Behaviors, Institutions and Organizations Across Nations. 2nd Edition. Thousand Oaks CA: Sage Publications.

Kohoutová, Z. (2012). Neodolal a koupil tričko Lacoste za polovinu. Byl to však padělek, (accessed May 05, 2012), [available at http://finance.idnes.cz/ padelana-tricka-lacoste-na-internetu-dvs-/viteze. aspx?c=A120402_143422_viteze_zuk].

Nevyhoštěný, J. (2012). Padělky luxusních značek lze koupit i na dobrých adresách, (accessed April 03, 2012), [available at http:// ekonomika.idnes.cz/padelky-luxusnich-znacekjde-koupit-i-na-dobrych-adresach-pz7-/ekonomika. aspx?c=A120403_154653_ekonomika_neh].

Nia, A., Zaichkowsky, J. L. (2000). Do counterfeits devalue the ownership of luxury brands? Journal of Product and Brand Management, 9 (7): 485-497.

Penz, E., Schlegelmilch, B. B., Stöttinger, B. (2009). Voluntary Purchase of Counterfeit Products: Empirical Evidence From Four Countries. Journal Of International Consumer Marketing, 21 (1): 67-84.

Solca, L., Wing, M., Rosso, A. (2010). European Luxury Goods: Long-Term Attractiveness \& Structural Demand Drivers. Black Book - European Luxury Goods: Long-Term Attractiveness \& Structural Demand Drivers, 1-96.

Štěrba, R. (2012). Metylalkohol má další obět', (accessed October 10, 2012), [available at http://zpravy.idnes.cz/ metyalkohol-zabil-muze-z-uherskohradistska- policistenasli-obri-sklad-13a-/ krimi.aspx?c=A121008_133308_ zlin-zpravy_ras].

Author

PhDr. Denisa Kasl Kollmannová, Ph.D. Head of Department Marketing Communication and Public Relations Faculty of Social Sciences Charles University in Prague Smetanovo nábřeží 6, 11000 Praha 1 kollmannova@fsv.cuni.cz 